\title{
Mekânlar ve Türler Karşılaștığında: Bir Osmanlı Venüs’ü
}

\section{When Spaces and Genres Intersect: An Ottoman Venus}

\section{Zeynep Nur Şimşek ${ }^{1}$ (I)}

'Bilkent Üniversitesi, Türk Edebiyatı Bölümü, Ankara, Türkiye

\section{ORCID: Z.N.S. 0000-0003-3400-7377}

Sorumlu yazar/Corresponding author: Zeynep Nur Şimşek,

Bilkent Üniversitesi, Türk Edebiyatı Bölümü, Çankaya, Ankara, Türkiye

E-mail: zeynepnursimsek@gmail.com

Bașvuru/Submitted: 21.10.2020

Revizyon Talebi/Revision Requested: 31.12 .2020 Son Revizyon/Last Revision Received: 25.01.2021 Kabul/Accepted: 16.02 .2021

\section{Atıf/Citation:}

Simsek, Z. N. (2021). Mekânlar ve türler karșlaştığında: Bir Osmanlı Venüs'ü. TUDED, 61(1), 303-318.

https://doi.org/10.26650/TUDED2021-813806

\section{ÖZET}

Yazdıkları romanların yanı sıra klasik şiir geleneğini devam ettirdikleri için edebiyat tarihinin "ara nesil" olarak adlandırdığı yazarlardan biri de Mehmed Celâl'dir. Romanları, sert çizgilerle kategorileştirilen klasik ve modern edebiyat ayrımına ters düşecek derecede melez yapıda olan Mehmed Celâl 1886 yılında, kendi deyimiyle, Venüs isimli bir "romancık" yazar. Mitolojik Venüs anlatısını dönüştürerek Osmanlı bağlamında yeniden kurguladığı novellasında farklı geleneklere ait edebî türler bir aradadır. Bu sayede, aruz kalıpları ile yazılıııs şiirlerin bulunduğu ilginç bir Venüs metni ortaya çıkar. Venüs'teki çeşitlilik sadece türlerle de sınırlı değildir. O dönemde yazılan romanlardan farklı olarak Venüs'te karşı cinslerin karşılaşma alanı deniz hamamlarıdır. Hikâyenin ana karakteri olan Şair, Venüs ismini verdiği sevgilisiyle İstanbul'un gizli kalmış ormanlarında görüşür. Onu, metinde kalabalıklara rastlanılan tek mekân olan deniz hamamında yüzerken izler. Mitolojik anlatıyla da denk düşecek şekilde Venüs, deniz ve tabiat tasvirleriyle birlikte anlatılır. Mehmed Celâl'in metnin başında yaptığı açıklamalar, sayfiye yerlerinde kurulan deniz hamamlarının dönemin halkı için alternatif bir kamusal alan teşkil ettiğini gösterir. Bu çalışma, arkaik Venüs anlatısının Osmanlı'daki bir yazar tarafından nasıl dönüştürüldüğünü görmeyi amaçlıyor. Henüz Latinize edilmediği için gölgede kalmış bu metni, türsel ve mekânsal çeşitlilikler üzerinden incelemeye açıyor.

Anahtar Kelimeler: Mehmed Celâl, Venüs, mitoloji, metinlerarasılık, deniz hamamları

\section{ABSTRACT}

Mehmed Celâl is among a group of writers called "the in-between generation" because they continued to produce classical poetry alongside new prose and verse forms, and his novels have a hybrid character that transcends the classical vs. modern dichotomy. In 1886, Mehmed Celâl wrote Venus, in which he transformed the mythological narrative of Venus, reconstructing it in the Ottoman context. In this novella, literary genres from different traditions coexist, producing an intriguing Venus text that contains poems written in classical Ottoman forms. Diversity in Venus is not limited to genre alone. Unlike other novels of the same period, sea baths in Venus are a place where one can meet members of the opposite sex. The main character of the story, the Poet, meets his lover whom he has named Venus in the hidden forests of Istanbul. He watches her swim in a sea bath, the only place where crowds appear in the text. Recalling mythological narratives, Venus is described alongside depictions of the sea and nature. Mehmed Celâl's statements at the beginning of the text demonstrate that the sea baths of that period constituted an alternative public space. This article aims to observe how the archaic Venus narrative was transformed by an Ottoman writer, and to assess Venus, an understudied text since it has yet not been Latinized, in terms of generic and spatial diversity.

Keywords: Mehmed Celâl, Venus, mythology, intertextuality, sea baths 


\section{EXTENDED ABSTRACT}

Based on Mehmed Celâl's novella Venus, this article aims to investigate the diversity of late Ottoman literature intrinsically and in relation to Greco-Roman mythology. In his novella, Mehmed Celâl transforms the mythological image of Venus into a local one. Having removed Venus from her mythological context, Mehmed Celâl chooses a most appropriate venue to match the archaic narrative: sea baths. As the only places in the text where crowds are encountered, Mehmed Celâl's depiction of sea baths provides important details in understanding gender roles in the period. Thanks to sea baths, the Poet has the opportunity to gaze upon his lover while she is swimming. Mehmed Celâl feared that these swimming scenes would attract negative attention, as it was uncommon for women to swim in public. He therefore provides information about sea baths in the preface to make it clear that his portrayal of them is accurate. He claims that swimming in the sea baths is common for both men and women in some districts of Istanbul, and that it is considered normal to see Christian women swimming in public. He demands that his readers not doubt his depiction and not regard these scenes as unusual.

Surrounded by wooden canopies, cliffs, and caves, the sea baths remained outside the usual narratives of public space in nineteenth-century Ottoman literature. Despite being a women-only space, historical records demonstrate that restrictions preventing access by men were easily overcome. Interestingly, the popularity of sea baths in the literary sphere suddenly grew after Venus. İbrahim Cemal published Deniz Hamamı Risalesi (Sea Bath Treatise) in 1890, seeking to answer all the questions that might arise regarding sea baths. His treatise includes a wide variety of information, from water temperature to wind direction, and it can be seen as an indicator of increasing interest in sea baths. These developments enable us to evaluate sea baths as a new public space in the late nineteenth-century.

Although Mehmed Celâl does not completely reject traditional forms of Ottoman poetry, he stretches its content by selecting a Roman goddess, Venus, as the subject of his work. He uses traditional Persian and Arabic phrases and "mazmuns" along with newly invented ones to build his narrative. Poems, written in a variety of classical Ottoman verse forms such as gazel and musaddas, incorporated into the prose sections and including correspondence work together to create a formally hybrid text. Mehmed Celâl not only transforms classical Ottoman poetry by utilizing mythological elements but also modifies the archaic narrative of Venus by Ottomanizing it. In some verses, he compares Venus to Zohra and refers to Venus as an angel rather than a goddess. After the publication of Venus, the number of books written on mythology increased remarkably. Famous Ottoman writers Şemseddin Sami and Nabizade Nazım each wrote a work of non-fiction titled Esâtir, and interest in classical mythology thrived in the Ottoman literary field. In short, all these developments helped to pioneer the movement of "Neo-Hellenism."

Consisting of forty-five pages of text, Venus is a striking novella that recreates mythological elements in the Ottoman context. As is clear from contemporary criticism, the subjects and 
forms he employed were not well-received in the literary circles of the period. Changes in literary taste left Mehmed Celâl and his texts forgotten and excluded from the literary canon. However, even if his novels are considered weak relative to current criteria, their hybridity contains clues essential to understanding the Ottoman novel and positioning it within world literature. 


\section{GíRIŞ}

Yazı hayatına 1884'te Tercümân-ı Hakikât'te başlayan Mehmed Celâl, ilk şiirlerini Fuzûlî, Nâilî, Nef'î ve Şeyh Gâlib gibi şairlerin etkisinde yazar (And1, 1995, s. 22). Çeşitli mecmua ve gazetelerde şiirler yazdıktan sonra 1886' da ilk romanı Venüs yayımlanır. Metninin girişindeki açıklamalarından da anlaşılacağı üzere, Mehmed Celâl ilk kez nesir formunda bir eser yazdığı için oldukça heyecanlıdır. Sebeb-i telif bölümlerini andıran bir yapıyla bu metni yazma amacını, kullandığı referansları, yazma ve isimlendirme sürecini birkaç sayfa boyunca açıklar. Ahmed Rasim'in tavsiyesi üzerine romanına Venüs ismini koyan Mehmed Celâl, Venüs'ün aslen Antik Yunan'da deniz köpükleri arasından doğan bir güzellik tanrıçası olduğundan ve kendisinin bu arkaik anlatıyı değiştirerek yeni bir kurmaca metin oluşturduğundan bahseder. Osmanlı İstanbul'unda yaşayan Şair ve Venüs ismini verdiği sevgilisi arasında geçen, faciaya dönüşen bir aşk hikâyesi yazdığını belirtir.

Mehmed Celâl, Venüs'ü yazdıktan sekiz sene sonra 1894'te yayımlanan Osmanlı Edebiyatı Numuneleri' nin “Büyük Hikâyeler ve Aksâmı” bölümünde romanın nasıl olmaması gerektiğini şu cümlelerle açıklar:

Acaba roman yazmaktan merâm, güzel bir kadın, sonra güzel bir delikanlı tasvîr etmek, kadını delikanlıya, delikanlıyı kadına bir rişte-i aşk ile rabt eylemek, sonra ortaya bir de rakib çıkararak, bir iki âdî entrika ile rakibi âzim-i semt-i adem edip, iki zavallının da hemen ekser-i hikâyelerimizde görüldüğü gibi kurban ederek işini bitirivermekten mi ibarettir?... Zannedersem hakikat böyle olmamal1. (Mehmed Celâl, 1894, s. 168-169)

Mehmed Celâl'in bu sözleri, aradan geçen süre zarfında roman hakkındaki fikirlerinin büyük ölçüde değiştiğini gösterir. Çünkü Venüs'ün olay örgüsü tam da Mehmed Celâl'in eleştiri getirdiği şekilde ilerler. Karakter yapısı klasik şiirin aşk üçgenini oluşturan âşık, mâşuk ve rakibi hatırlatan Venüs'te olaylar melodramatik bir üslupla anlatılır. İki sevgili, Şair'in kısa süreliğine bir yolculuğa çıkması üzerine ayrı kalırlar. Klasik şiirde "Yüzü kara", "Rû-siyah" gibi ifadelerle nitelendirilen rakibin Venüs’teki karşılığı ise siyah arabasıyla gelen bir genç olur. Venüs bu genci görünce Şair'i unutur. O da tıpkı mâşuk gibi vefasızdır. Venüs her ne kadar çok geçmeden yaptıklarından pişman olsa da ihaneti Şair'i intihara sürükler. Şair'in, kalbine hançer saplayarak intihar etmesi üzerine karşılaştığı manzaraya dayanamayan Venüs, sevgilisinin göğsündeki hançeri çıkararak kendini öldürür. Metin, sevgililerin aynı mezara gömülmesi sahnesiyle kapanır. Mehmed Celâl böylece iki sevgiliyi "kurban ederek işini bitirivermekten ibâret" bir roman yazmış olur. Roman türü hakkındaki açıklamaları, geçmişte yazdığı bu metinle arasına mesafe koymuş olduğunu gösterir.

Yıllar sonra Venüs'e getirdiği özeleştiriye rağmen Mehmed Celâl, romanını yeni yazdığı dönemde kendisine yapılan eleştirilere karşı kayıtsız kalmaz. Hüseyin Cahit ile "Dekadanlar" tartışması üzerine başlayan ve ağır hakaretlere varan yazışmaları genellikle Mehmed Celâl'in romancılığı üzerinden ilerler. Hüseyin Cahit bir yazısında Mehmet Celâl'in romanlarını birbirine 
benzemekle suçlar. Onun külliyatını anlamak için tek bir romanını okumanın yeterli olduğunu iddia eden Hüseyin Cahit bu metinleri şu cümlelerle özetler:

Külliyetli miktarda esatir perisi, bir hayli çiçek ve kelebek, beş on tane şafak bulutu, bir iki adet mehtap ve tulû-1 afitab, birçok sarı saç, mavi göz alınıp seher vakti hepsi bir yerde kelimat-1 aşk ve muhabbet ile bol bol karıştırıldıktan sonra Büyükada'nın çamları altına serpilir ve icabı takdirinde biraz akarsu, bir miktar çimen ve bülbül ilave edilirse derd-i mütalâadan insanı şifayab edecek surette müessir bir tertip vücuda geliyordu. (akt. Gökçek, 2014, s. 142)

Hüseyin Cahit'in ağır ithamlarına karşı Venüs'ün İngiliz şair Mr. Gibb tarafından takdirle karşılandığını belirten Mehmed Celâl, Fransızca bilmeden böyle bir roman yazabildiği için kendisiyle gurur duyar (And1, 1995, s. 24).

\section{Venüs İstanbul'da}

Venüs 'ün ilk sahnesi bir yaz günü İstanbul boğazının oluşturduğu güzel manzarayı seyreden bir gencin tasviriyle açılır. Okurları duygu yüklü bir metnin beklediği daha ilk cümlelerden anlaşılır. Tebessüm ederken ağlamaya başlayan, elleri ve sesi titreyen kırılgan karakterler anlatıcı tarafından yüceleştirilir. Metin ilerledikçe, ağlayan bu gencin Şair, ağlama nedeninin ise Venüs ismini verdiği sevgilisi olduğu ortaya çıkar. Şair ile Venüs kalabalıklardan uzak sayfiye ortamının verdiği imkânlar sayesinde çoğunlukla dış mekânlarda buluşurlar. Bu ikilinin aşkı yoğun tabiat tasvirleriyle birlikte işlenir. Hikâye her ne kadar İstanbul'da geçse de tasvir edilen mekânlar çoğunlukla tabiatın içindedir. Bu sayede, dış mekân anlatılarının yoğunluğuna rağmen Şair ve Venüs'ün aşkı tabiatın romantize edilmesi sayesinde saklanır; anlatı boyunca gizli kalır. Hatta öyle ki, bulutlar bile bu yüceleştirilmiş aşkı kimsenin görmemesi için kendilerine düşen görevi yaparlar: "Şair bûse-i vedâ olmak üzere Venüs'ün gül rengindeki yanağına gonca gibi kızarmış olan dudaklarını dokundurdu. Tabiat, bu manzarayı dîde-i ağyardan nihân etmek için o esnada cihâna nurefşân olan mâh-1 münevverden üzerini hafif bir bulut ile kapadı" (Mehmed Celâl, 1886, s. 14). Böylece Şair ve Venüs’ün aşkı yabancı bakışlardan uzak, doğanın kendisi kadar doğal, onunla uyumlu ve yeri geldiğinde de vahşi olabilmektedir.

Hikâyedeki tabiat vurgusu, sadece mekânlarla sınırlı kalmaz. Sarı saçları ve mavi gözleriyle Venüs, Farsça tamlamalar ve benzetmeler kullanılarak doğayla bütünleştirilir; onun bir parçası hâline getirilir. Ancak Venüs, her ne kadar hikâyenin baht dönüşlerine sebep olan eylemlerde bulunsa da bir vücut olmaktan öteye gidemez. Anlatıcı, pek çok yerde Venüs'ü tasvir ederken onun sadece bedensel özelliklerine vurgu yapar:

Şair birdenbire durdu. Denize doğru eğilen siyah kayaların birinin üzerinde beyazlara bürünmüş bir vücut gördü. Vücuda yaklaştı. Mehtabın yardımıyla o vücudun çehresini de seçebildi. O çehreye inkişâf eder etmez âteşîn yanakları sararmaya, dudakları titremeye, kalbi şiddetle çarpmaya başladı. Oracığa düşüp kalmamak için sahildeki 
ağaçlardan birine dayandı. O çehreyi temâşâya daldı! Gördüğü çehre Venüs'ün yüzüydü. (Mehmed Celâl, 1886, s. 12)

Venüs'ün hikâyedeki işlevi güzel vücudunu sergilemek ve bu sayede karşısındakine acı vermektir. Şair de anlatıcı gibi Venüs'ü bedeni üzerinden var eder; aşkını bu beden üzerinden yaşar. Öyle ki: "Mevki seninle şâirâne olur. Senin vücudunla burası bir levhâ-yı latîf hâlini alır. Seni burada görenler, Venüs beyaz vücudunu örtmek için arkasına deniz köpügünden mahluk bir gömlek giymiş, eline şafak bulutundan mevcut bir demet çiçek almış, ağaçların arasında saklanmış zanneder" (Mehmed Celâl, 1886, s. 9) diyerek mitolojik anlatıya da eş düşen bir tasvirle Venüs'ün vücuduna odaklanır. Şair, roman boyunca sık sık iki şeyi temaşa eder: tabiat ve Venüs'ün vücudu.

Venüs'teki tasvirler, kadınlığı vücuda indirgeyerek onu tabiatın güzel ve vahşi bir parçası hâline getirmelerinin yanı sıra anlatıyı görsel açından zenginleştirme işlevine de sahiptir. Anlatıcı manzarayı tasvir ederken 1şığın tonunu, çeşitliliğini spesifik olarak belirtir. Doğa tasvirlerinin yoğunluğu arasında karakterler de bulundukları ortama uygun poz verirler. Venüs'ün:

Saçları yastığın üzerine saçılmış ve kirpikleri yanaklarına doğru temâşâsına doyulmaz gölgeler bırakmış, ellerinden biri kalbinin üzerine, diğeri gelişi güzel yanına düşmüş, sağ bacağı dizine kadar sıyrılarak yorganın altından çıkmış, o esnada envâr-1 hurşîdin pembe cibinlik üzerine aksi de şafak bulutları arasından güneşin doğuşuna yakın bir manzara husûle getirmişti. (Mehmed Celâl, 1886, s. 33-34)

şeklindeki tasviri, bir tablodan yola çıkılarak oluşturulmuş gibidir. Bu tarz tasvirlerin çokluğu metni görsellik açısından zenginleştirirken bir yandan da karakterlerin içini boşaltır; tikelleşmelerini engeller. Mekân ve karakterlerin yoğun görselliği, onları iki boyuta düşürerek derinlikten mahrum birakır. Karakterlerin abartılı hassasiyetleri de bu durumu destekler: "O kadar ağlıyorlar ve bu giryeler arasında öyle acı tebessümler gösteriyorlardı ki o manzarayı görüp de eşkrîz teessür olmamak kâbil değildi” (Mehmed Celâl, 1886, s. 36). Bu denli dramatik sahnelerin anlatıcısı, okurundan da aynı duygusallığı talep eder. Çoğu yerde okurlarına sorular sorarak onları da bu duygu selinin içerisine sokmak için elinden geleni yapar.

\section{Alternatif Kamusal Alanlar: Deniz Hamamları}

"Herkes yüzmekle ve bu yüzmek esnasında birbirleriyle şaka ederek konuşmakla meşguldü” (Mehmed Celâl, 1886, s. 24).

Mehmed Celâl, Venüs’ün mitolojik bağlamını dönüştürerek onu yerel bir anlatı içerisinde yeniden kurgularken mekân olarak -Tanrıça Venüs'ün denizden doğduğu düşünüldüğündemitolojik anlatıyla en uyumlu yeri seçer: Deniz hamamları. Deniz hamamlarının ortaya çıkışı ile ilgili net bir tarih bulunmasa da 1872 yılında tutulan kayıtlara göre İstanbul'da yirmi sekizi kadınlara, otuz dördü erkeklere mahsus toplamda altmış iki deniz hamamı bulunmaktaydı (Beyoğlu, 2004, s. 59). Bu sayılar, denize girme konusunda kadınların erkeklerden pek de 
geri kalmadığını gösterir. Denize çakılı kazıkların üzerine kurulan bu odacıklar, çok geçmeden insanların uğrak mekânı hâlini alır. Saray halkı ve yalı sahiplerinin hususi deniz hamamları daimi olarak kurulu dururken umumi hamamlar yaz başında kurulur, tahtaların çürümemesi için havalar soğuduğunda bunlar sökülür (Alus, 1950, s. 5). Az bir ücret karşılığında herkesin girebildiği umuma açık deniz hamamları her sınıftan ve milletten insanı aynı yere toplama gücüne sahip ender mekânlardandır. Sermet Muhtar Alus'un deniz hamamlarına dair anıları bu mekânların bir zamanlar ne kadar canlı olduğunu bir kez daha gösterir. Alus'un zihninde, çocukluğunda gittiği deniz hamamlarından geriye deniz elbiseleri içinde ud ve tef eşliğinde dans ederek eğlenen kadınların görüntüsü kalır (Alus, 1947, s. 4). Venüs'te de benzer sahnelere rastlanır. Ancak Mehmed Celâl, hikâyenin büyük bir kısmının geçtiği deniz hamamlarını ve buradan hareketle oluşturulmuş kamusal alan anlatısını okuyucuların abartılı bulacağını düşünmüş olacak ki öncesinde, anlattıklarının gerçek olduğunu açıklama gereği duyar. Okurları birazdan okuyacakları konusunda yanlış çıkarımlara varmamaları için uyarmak ister:

İleride de görüleceği vechile romanın bir bâbını yalnız deniz hamamı âlemini tavsîfe hasrettim. Bunda bazı Hıristiyan kadınlarının açığa çıkarak aşikâr yüzdüklerine, yüzmeye ait bazı hareketlerine dair verdiğim malûmat erbâb-1 mütalâaya ayıp gelmemelidir. Bu hâl pek tabiileşmiştir. Deniz hamamı zamanlarında Büyükdere ve emsâli yerlerde o gibi manzaralar hemen her sabah görülebilir. Bir manzara-i tabiiyi etrafiyla tasvîr eylediğimden dolayı muharrirlik vazîfesini bihakkın îfâ ettiğime kâni' olan erbâb-1 insâf maksadımın tasvîr-i hakîkatten ibaret bulunduğuna şüphe etmez. Şu ilk eserimde görülecek kusurların ise adem-i budû'uma, hadâset-i sinnime bağışlanacağıma eminim.” (Mehmed Celâl, 1886, s. 3-4)

Metinde kalabalıklara rastlanabilecek tek yer olan deniz hamamları dönemin cinsiyet rollerini anlamada önemli ayrıntılar barındırır. Mehmed Celâl metne eklediği ön sözde Büyükdere gibi semtlerdeki deniz hamamlarında Hıristiyan kadınların açıkta yüzdüklerinden ve bu durumun normal karşılandığından bahseder. Okurlarından, bir yazarlık görevi olarak gerçekleri anlattığından şüphe duymamalarını, bu sahneleri garip karşılamamalarını ister. Mehmed Celâl'in asıl çekincesi kadınların deniz hamamlarında yüzmeleri üzerine değildir. Çünkü, 19. yüzyılın ortalarından itibaren hızla gelişen deniz hamamı kültürüne okurların da aşina olması gerekir. Venüs'teki aşırılık kadınların deniz hamamlarından çıkarak dönemin mahremiyet normlarına aykırı davrandıkları sahnelerden kaynaklanır. Kadın ve erkeklerin birbirlerini görmemeleri için tahta perdelerle çevrili olan deniz hamamları, sandalla devriye gezen zabıtalar tarafından korunmaktaydı. Ancak, Reşat Ekrem Koçu'nun tecrübelerine göre sıkı denetlemelere rağmen kuralların aşıldığı zamanlar oluyordu. Bazı erkekler kadın hamamını gizli yollardan gözetlemeye çalışıyor, bunun için türlü yollara başvuruyordu (Koçu, 1966, s. 4439). Mehmed Celâl'in tepki almaktan korkmasının nedeni romandaki kadınlar ve erkeklerin mahremiyet sınırlarına aykırı davranışlarda bulunmasından kaynaklanır. Şair, kadınlara mahsus deniz hamamını yukarıdan gören bir kayaya çıkarak ilk sınırı aşar. Ancak buna rağmen anlatıcı, Şair'e olan güvenin kırılmasını istemez ve okurların kafasında oluşabilecek “Acaba deniz hamamlarının kapakları önünden çıkan güzel kızların nurdan mahlûklar denilecek kadar şaşalı pazularını, beyaz 
bacaklarını âteşîn çehrelerini seyretmek için mi oraya oturmuştu?" sorusunu kendisi sorarak cevabını da peşinen verir: "Hayır! Yolu oraya tesâdüf etmişti. Şairimiz deniz hamamlarına böyle bakmıyordu” (Mehmed Celâl, 1886, s. 24). Anlatıcı, okurları Şair'in masumiyetine inandırmaya çalışırken kuralları aşan taraf kadınlar olur. İçlerinde Venüs'ün de bulunduğu bir grup kadın deniz hamamının dış tarafında yüzmeye başlar. Kadınların serbestlikleri ve çevrenin bu duruma tepkisizliği çoğunlukla yan yana inşa edilen erkeklere ve kadınlara mahsus deniz hamamlarında cinsiyetler üzerinden belirlenen kuralların aşılabilir olduğunu gösterir. Bu sayede, deniz hamamları kadın ve erkeklerin bir araya gelmelerine imkân veren yeni bir kamusal alan oluşturmuş olur. Şair de bu imkândan faydalanarak, "kostüm” adı verilen denize mahsus bir kıyafet içerisinde yüzmekte olan Venüs’ü uzun uzun temaşa eder:

Kadınların yüzmesi ne kadar latîftir! Beş altı tanesi denize girseler meleklerin esvâplarını gökte bırakıp denize indiklerini tasvîre çalışıyorlar, zannolunurdu. O gün en evvel denize gayet güzel bir kız girdi. Bu kız denize mahsus olan ve bacaklarının yarısından tut da göğüs, memeleri bile setreden kostüm namındaki deniz esvâbını giymiş perişân saçları da yüzüne doğru saçılmış idi. (Mehmed Celâl, 1886, s. 24)

Venüs'ün 1886' da yazıldığı düşünüldüğünde, bu tarihten önce yazılan Osmanlı romanlarında mesire alanları ve millet bahçeleri dışında karşılaşabilen kadın ve erkeklere, yüzen bir sevgiliye rastlamak Mehmed Celâl'in önsözdeki uyarılarından da anlaşılacağı üzere oldukça istisnai bir durumdur. Deniz hamamı sahnelerinde kadın vücudunun:

Güzel bacaklarını, latîf pazularını aheste aheste açıp kapıyor ve bu hareketten kızın mini mini ayaklarını, pertevli gerdanını birer parça deniz köpüğü tezyîn ediyordu. Ara sıra uzun siyah saçlarının arasında görülen ufak ufak köpükler karanlık gecelerde gün yüzünde parıl parıl parlayan yıldızlara benziyordu! (Mehmed Celâl, 1886, s. 25)

şeklinde tasvir edilmesi mitolojideki deniz köpükleri arasından çıkan Venüs anlatısıyla benzerlik taşır. Birbiriyle yüzme yarışı yapan kadınların anlatıldığı bir sahnede tabiattan "Sanki tabiat, melâhatları bir derecede olan bu iki meleğin yekdiğerine müsâbakâtına razı oluyormuş da birbirini geçmemeleri için o anda ikisinin de kuvvetini bir dereceye indirmiş" (Mehmed Celâl, 1886, s. 25) şeklinde bahsedilmesi onu, yüzen kadınların arasındaki üçüncü bir kişi kadar canlı ve bilinçli bir yapıya büründürür. Tüm bunlar, dış mekân anlatılarının metindeki yoğunluğu sayesinde oluşur.

İlginçtir ki Venüs yayımlandıktan sonra on y1l içerisinde deniz hamamları ile ilgili bilgi içerikli üç kitap yayımlanır. ${ }^{1}$ Bunlardan ilki olan Deniz Hamamı Risalesi’nde (1890) İbrahim Cemal deniz hamamlarına dair akla gelebilecek bütün sorulara detaylı cevaplar verir. Metinde kimlerin, ne zaman, nerede ve nasıl deniz hamamlarına girmesi gerektiği bölümler hâlinde açıklanır. Suyun sıcaklığından, rüzgârın esiş yönüne kadar her türlü bilginin yer aldığı bu risale,

1 Birbirine benzer içerikteki bu üç metnin amacı okurları deniz hamamları hakkında bilgilendirmektedir. Deniz Hamamları Risalesi'nden üç yıl sonra Hüseyin Hulki Deniz Hamamlarl ve Kimler Girmelidir?'i yayımlar. Bu metinden yedi sene sonra ise Celal İsmail Paşa’nın Deniz Havası ve Hamamları yayımlanır. 
deniz hamamlarına artan ilginin bir göstergesidir. Nitekim 1875 'te İstanbul Şehremaneti deniz hamamları hakkında bir nizamname çıkarır. Nizamnamede getirilen sınırlamalara göre, kadın ve erkekler için ayrı olması kararlaştırılan deniz hamamlarının belli ölçüler dâhilinde, sadece izin verilen semtlerde yapılandırılması şart koşulur (Toprak, 2018, s. 16). 1877'de çıkarılan Vilayet-i Belediye Kanunu'nda sahili olan mahallelere deniz hamamlarının yapılmasına ve böylece halkın açıktan suya girmesinin engellenmesine karar verilir (Beyoğlu, 2004, s. 60). Tüm bu gelişmeler, Mehmed Celâl'in 1886' da yazacağı Venüs romanı için bir alt yapı oluşturur. Deniz hamamlarının kurallara tabi tutularak devlet eliyle düzenlenmesi, 19. yüzyılın ikinci yarısından itibaren bu mekânları yeni bir kamusal alan olarak değerlendirme imkânı sağlar. Venüs ise bu noktada, Osmanlı kamusundaki değişimleri gösteren tarihi bir belge niteliğinde bilgiler sunar.

\section{Kesişen Dünyalar, Geçişken Türler}

“Gör dâimâ önünde esâtir-i evvelin Gökten dehâ-yı nârı çalan kahramanını" (Tevfik Fikret, 2017, s. 25).

Venüs'ün içeriğindeki çeşitlilik biçimsel olarak da görülür. Mehmed Celâl oluşturduğu bu metne "romancık" demekte haklıdır; çünkü Venüs dil, içerik ve biçim açısından roman türünün sunduğu özgürlük vaadini kullanan bir metindir. Günlük dilin yanı sıra Farsça ve Arapça tamlamaların metindeki varlığ 1 anlatıyı dilsel olarak çeşitlendirir. İçinde mektuplaşmaların da bulunduğu mensur bölümler sürekli araya katılan farklı nazım türlerindeki şiirlerle birlikte türler arası geçişliliğin yoğun olduğu bir metnin ortaya çıkmasını sağlar. Venüs’teki şiirlerde, klasik şiirin hayal dünyasının dışına çıkıldığını gösteren unsurlar bunulur. Mehmed Celâl'in Venüs'te yaptığı yenilikler Gibb’in 1859 sonrası klasik şiirin dönüşümü hakkındaki şu sözleriyle daha iyi anlamlandırılabilir: "Gelenek ve âdetlerin katı kuralları bir kenara itilecek; şair, nereden istiyorsa ilhamını oradan alacak ve neyi söylemek istiyorsa, içinde olan her şeyi söyleyebilecek bir özgürlüğe kavuşacaktır” (s. 514). Venüs’teki şiirler, Gibb’in bahsettiği özgürlük talebinin bir uzamı olarak değerlendirilebilir. Mehmed Celâl, her ne kadar geleneği tamamen reddetmese de kendisine seçtiği yeni ilham kanalları sayesinde sınırları ve kalıpları esnetir. Antik Yunan ve Roma mitolojisini klasik şiire taşıyarak ortaya melez bir ürün çıkarır. Burada asıl önemli husus, Mehmed Celâl'in mevcut konvasiyonun dışına neden ve nasıl çıktığı sorusudur. Çünkü Mehmed Celâl Venüs'ü, ilerleyen yıllarda Antik Yunan anlatılarına karşı uyanacak ilgiden görece erken bir tarihte yazar. Hem de bunu Fransızca bilmeden yapar.

Mehmed Celâl'in ve ona romanına Venüs ismini vermesi gerektiğini söyleyen Ahmet Rasim'in Antik Yunan ve Roma mitolojisi hakkında okuyabileceği sayılı kaynak bulunmaktaydı. Ancak tercüme eserlerin kıtlığına rağmen Osmanlı yazarı Yunan mitolojisine tamamıyla yabancı değildi. Süheyla Yüksel'in araştırmalarına göre, Mehmed Celâl'den önce Namık Kemâl, Recâizade Mahmut Ekrem, Abdülhak Hâmit, Cenap Şehabettin gibi isimler şiirlerinde mitolojik figürlere yer vermiş ve bu yeni hayal dünyasına uygun mazmunlar kullanmışlardı. Venüs de 
bu figürlerden biri olarak "âlihetü'l hüsn", "âlih-i naz" gibi tamlamalarla şiire dâhil edilmiş ve çoğu zaman Zühre'yle birlikte anılmıştı (Yüksek, 2010, s. 175-183). Mehmed Celâl'in yenilikçiliği ise mitolojik karakter ve unsurları birkaç beyitte değil, eserlerinin tamamında işlemesinden kaynaklanmaktaydı. Tüm bunlar düşünüldüğünde, Tanzimat sonrasında Antik Yunan kültürüne ilginin arttığı doğruydu. Fakat Strauss'a göre bu ilgi Osmanlı' daki Müslüman Türkler, Araplar ve Yahudiler arasında kayda değer bir popülerlik kazanamamıştı. Antik Yunan eserlerinin ilk çevirileri genellikle gayrimüslimler tarafından yapılmıştı. Bu eserler ilk kez Karamanlıcaya 1819'da çevrilmişti. Ardından 1837'de Ermeni harfleriyle Türkçeye, 1838'de ise Arap harfleriyle Türkçeye çeviriler yapılmıştı (Strauss, 2014, s. 25-26). Osmanlı çeviri tarihinde önemli bir yere sahip olan Telemak 1859 yılında hem Ermeniceye hem de Türkçeye çevrilmişti. Bu tarihten önce Fransızcasından okunan metnin Yunanca ilk çevirisi 18. yüzyıla dek uzanmaktaydı (Strauss, 2014, s. 29).

Homerik metinlerin Osmanlı Türkçesine çevrilmesine dair ilk adımlar ise 1870’leri bulur. 1870 yılında Maarif Nazırı Saffet Paşa tercüme odası çalışanı Konstantin Efendi' den Yunan-1 Kadim Tarihi çevirisi yapmasını ister. Daha sonradan Sadullah Paşa manzum ve mensur karışık bir İlyada çevirisine başlar. Ancak bu teşebbüsler yarıda kalır (Tökel, 2000, s. 73). Bundan sonraki Homeros çevirileri ise 1886 'dan yani Venüs'ten sonra yapılır.

Mehmed Celâl'in Antik Yunan ve Roma mitolojisine dair bilgi edinebileceği kaynaklar temel olarak bu metinlerle sınırlı gözükmektedir. Mehmed Celâl'in bu kaynaklardan hangilerini okuduğunu bilmek mümkün olmasa da romanını yazmadan önce Venüs hakkında okudukları veya duydukları onun hayal dünyasını büyük oranda şekillendirir. Zaten Mehmed Celâl'in Venüs'ü yazarken ana metne sadık kalma gibi bir arzusu ve iddiası yoktur. Onun amacı Venüs'ten hareketle Osmanlı' da geçen lirik bir roman yazmaktır. O zamana kadar şair kimliği ile tanındığı için ilk romanını yazarken araya anlatıya uygun şiirler eklemekten kendini alıkoyamaz. Ana karakterini de sadece şair kimliği üzerinden var eder. Şairin Venüs'e söylediği her şiirle birlikte mitolojik öğeler klasik nazım şekillerine taşınır. Böylece hem Antik Yunan mitolojisi hem de klasik şiir Mehmed Celâl aracılığıyla dönüşüme maruz bırakılır. Bu şiirlere yakından bakmadan önce, Walter Andrews'ün gazel ve klasik şiirin metinlerarasılığını vurguladığı açıklamasına kulak vermenin gerekli olduğunu düşünüyorum. Andrews'e göre gazeller de diğer şiir türleri gibi “aynı anda birçok şey olan metinler” sınıfına girerler; belli bir yer, zaman ve kültürdeki motivasyonları taşırlar. Bu şiirler "son derece karmaşık bir sosyo-kültürel bağlam içinde yer alan -çok sayıdaki ve sık sık çatışan motivasyon ve ihtiyaçları yansıtan- olağanüstü yetenekli bireylerin ürünleridir (Andrews, 2012, s. 21). Andrews, klasik şiirin farklı kültürlerle etkileşim hâlinde olduğundan bahsederken bu şiir geleneğinin sanıldığ 1 gibi kapalı bir anlam dünyasına sahip olmadığını öne sürer. Her metin gibi gazellerin de metinlerarası dinamikleri vardır. Şiirin kültürel ortakları ve bağlamları sürekli bir etkileşim süreci içinde şiiri şekillendirir ve şiir tarafından şekillenir (Andrews, 2012, s. 21). Mehmed Celâl'in şiirleri Andrews'ün şiir tanımına oldukça uygundur. Antik Yunan ve Roma mitolojisi Mehmed Celâl'in şiirlerini şekillendirirken, kendisi de bu şiirler tarafından yeniden şekillenir. Mehmed Celâl'in romanını okuyan dönem okurlarının zihninde Venüs, deniz hamamlarında yüzen güzel bir kız olarak canlanır. 
Metindeki şiirlerden ilki, Venüs’ün albümünden kendi tasvirini Şair’e vermesi üzerine yazılır. Şair'in bir mektuba yazdığı "Tasvirine” redifli gazelin bazı beyitleri şunlardır:

Her ne dem baksam verir cisme hayat-1 câvidân

Söyle kim verdi hayat câvidân tasvîrine?

Öyle dilbersin ki kâfirler de tercîh etmiyor

Meryem'in tasvîrini ey dilşân! Tasvîrine!

Nûr içinde doğdu hurşîd-i cihân zanneylerim

Mehtâb olsa eğer pertev-feşân tasvîrine!

Seyre dalmıştım tasâvîrin bütün dilberlerin

İn‘itâf etti nigâhım nâgehân tasvîrine!

Külbe-i ahzânda her şeb âşıkla söyleşir

Hazret-i Allah vermiştir lisân tasvirine

Muhtazır bir hasta gördü cismine geldi hayât

Cân verirken baktı oldu şâdmân tasvîrine!

Korkarım aklım gider seyr eylerken vechini

Nûr-1 aynım! Bakmak olmaz her zamân tasvîrine! (Mehmed Celâl, 1886, s.18-19).

Görüldüğü üzere Şair, gazelinde klasik şiirin alışılageldik tamlamalarını kullanır. Mehmed Celâl'in çoğu kadın karakteri gibi Venüs de sarışın, mavi gözlü olduğu için klasik şiirin siyah saçlı güzellerinden daha farklı tasvir edilir. Ancak bu farklılığa rağmen Venüs için de gül, güneş, ay, tabib gibi benzetmeler kullanılır.

"Mâi Gözler" başlıklı ikinci şiir de ilk şiir gibi Şair'in Venüs’e gönderdiği bir mektupta yer alır. Şiirin beşinci kıtası olan bu dizelerde Venüs ile Arap literatüründeki karşılığı olan Zühre'nin yan yana kullanılışı içeriği melezleştirir:

Cûş ederdi gül yüzünden pertev-i ruhsâr-1 âl

Zan ederdim durdu karşımda Venüs ya bir hayâl!

Kalmadı sabrım - ve ismini ettim suâl

“Zühre'yim! İndim semâdan!” derken ol kudsî cemâl,

Gönlümü verdim nigâh-1 nâzenîn nîrengine

Âşık oldum çeşm-i dildârın semavî rengine! (Mehmed Celâl, 1886, s. 22).

Afrodit ve Venüs’ün doğu mitolojilerindeki Zühre anlatısıyla benzerlikleri aslına bakılırsa oldukça yüzeyseldir. Buna rağmen, aynı gezegeni temsil ettikleri için Osmanlı' da ve günümüzde de sıklıkla beraber anılırlar. Şair, romanda sevgilisi Venüs'e birkaç kez Zühre 
diye seslenir: “Allah'ım! Nedir bu cazibe! Zühre'yi mi görüyorum? Odanın içine nur mu iniyor?” (Mehmed Celâl, 1886, s. 15). Zühre'nin mitolojide “Allah'ın şehveti mücessem bir şekilde indirdiği bir kadın” (Tökel, 2000, s. 358) şeklinde tanımlanması Venüs ile ortak noktalarından birini oluşturur. Çünkü Venüs, güzelliğin, aşkın, şehvetin ve cinselliğin tanrıçasıdır. Keza romanda da Venüs'ün ilahi özelliklerine vurgu yapılır. Şair'in deniz hamamında yüzen kadınları gördükten sonra yazdığı bu dizelerde Venüs'ün doğuşuna bir atıf vardır. Şair bu seferki şiirini Venüs'ün yüzerkenki görüntüsünden ilham alarak her zaman yanında taşıdığı defterine not düşer:

Deryâya atıldı bir güzel kız

Deryâya cemâli saçtı yaldız!

Ol şey ne kadar da pertev-efzâ

Yüzmekte Venüs denizde gûyâ!

Manzûr oluyor cihâna işte

Pertevler içinde bir ferişte (Mehmed Celâl, 1886, s. 8)

Venüs, metin boyunca pek çok kez etrafına 1şık saçan bir yıldız olarak tasvir edilir. Venüs'e dair semavi çağrışımlar yalnızca gezegenlerle de sınırlı kalmaz. Şair roman boyunca sevgilisini en çok "melek" ve "ferişte" sıfatlarıyla çağırır; şiirlerinde de bu tarz benzetmelerde bulunur. Aşağıdaki şiirler Şair’in Venüs'ü gördüğünde gözyaşları içinde irticalen söylediği şiirlere örnektir. Romandaki bu tarz şiirler bazen diyaloglarda bazen de Şair'in kendi kendine mırıldanmasıyla ortaya çıkar. Bu şiirler, mektuplaşmalardaki şiirlere oranla oldukça kısadır:

Tehîm midir o peri çehreye melek dediğim

Cemâl ilâhesi, bir dilber-i semâvîdir!

Bakın! Ki ol melek-endâm tatlı tatlı bakar

Nigâhı câzibeli, gözleriyse mavidir! (Mehmed Celâl, 1886, s. 11).

$* * * *$

Duyunca âlem-i lâhûta uçmuş sanırım

Melek sedâsına benzer terâneniz vardır! (Mehmed Celâl, 1886, s. 14).

Venüs 'teki şiirler, Mehmed Celâl'in klasik şiirin hayal dünyasından tam olarak kopamasa da onu Antik Yunan mitolojisine ait unsurlarla dönüştürdüğünü gösterir. Şiirlerde kullanılan tamlama ve teşbihlerin benzerleri metnin nesir kısımlarında da karşımıza çıkar. Romanın ana karakterinden "Şair” olarak bahsedilmesi akıllara klasik şiirin âşığını getirir; çünkü klasik şiirde şair âşığın kendisidir. Venüs ise bu aşk ilişkisinin mâşuk rolünü üstlenir. O da divan güzelinin sahip olduğu uzun kirpiklere, siyah olmasa da perişan saçlara sahiptir. Âşık yani Şair onu gördüğü zaman hastalanır, göz yaşları içinde kalır. Venüs arketipinin özelliklerinden ihanet eden ve can yakan kadın tipi romanda da karşımıza çıkar. Venüs vefasızlığı yüzünden anlatıcı tarafından sert bir dille yerilir. Tıpkı Şair gibi anlatıcı da Venüs'ü melek olarak nitelendirirken ihanetle birlikte tavrını aniden değiştirir; Venüs için "zalim", "hain", "bivefa" gibi sıfatlar kullanmaya başlar. 
Mehmed Celâl'in diğer eserlerinde de mitolojiye, özellikle de Venüs'e dair öğelere sıklıkla rastlanılır. Konusunu mitolojiden alan ikinci romanı Orora'da (1888) Orora'nın (Aurora) Venüs'ten dünyaya gelmiş bir melek kadar güzel olduğunu belirterek Antik Yunan mitolojisinden² eserler vermeye devam ettiğini yazar. ${ }^{3}$ Yayın tarihi belli olmayan bir diğer romanı Leman' da Venüs objeleri ve tasvirlerine yer verir. Mehmed Celâl 1899 'da, Venüs'ten on üç yıl sonra, Venüs hakkında yazdığı şiirlere bir yenisini ekler. Venüs'ün doğuşunu anlattığı şiiri "Venüs Denizden Çıkıyor" Mâlûmât mecmuasında yayımlanır. ${ }^{4}$

Osmanlı'nın son yıllarında Antik Yunan ve Roma mitolojilerine olan ilgi sadece Mehmed Celâl'le sınırlı kalmaz. Venüs'ün yazıldığı tarihten itibaren mitoloji alanında basılan kitaplardaki artış dikkat çekicidir. Venüs’ten bir yıl sonra M. Naim Fraşeri'nin İlyada çevirisi yayımlanır. Ancak kitap, orijinal metnin sadece bir kısmını kapsar. 1890'da yayımlanan Esâtir sadece Yunan ve Roma değil, farklı kültürlerden birçok mitin tanıtıldığı bir başvuru kitabıdır. Şemsettin Sami, Esâtir' de Venüs'e yalnızca bir sayfa ayırarak şu tanımlamayı yapmakla yetinir: "Venüs denizin köpüklerinden tevellüd idüp, hüsn ü cemâlin ilâhesi, aşkın vâlidesi, gülmenin ve zevk ve eğlence ve nazın melikesi ve âşıkların hâmîsi idi” (Şemsettin Sami, 1890, s. 18). 1893'te bu sefer Nabizade Nazım'ın Esâtir'i yayımlanır. Sadece yirmi dört sayfadan oluşan bu çalışma mitoloji hakkında temel bilgilerden oluşur. Osmanlı'da Antik Yunan kültürü ve mitolojisi hakkında en kapsamlı çalışma ise Mehmed Tevfik Paşa tarafından yapılır. 1913 yılında yayımlanan Esâtir-i Yunaniyyan, mitolojik karakter ve olaylar hakkında detaylı bilgiler içerir. Heykel ve tablolara ait fotoğraf ve tasvirlerle zenginleştirilen bu metin, övgülerle karş1lanır. Metin, Abdülhak Hamid' in “Bu tarihi bilmek gerek mutlaka / Bütün Müslümanlarla Osmanlılar / Bilinsün tedennî veya irtikâ / Nasıl eylemiş Eski Yunanlar” (Mehmed Tevfik, 1913, s. 1) dizelerinin de bulunduğu övgü yüklü şiiriyle açılır. Otuz altı sayfalık bir bölümle Venüs ve Afrodit ayrıntılı bir şekilde anlatılır. Aynı yıl yayımlanan Süleyman Tevfik'in Pierre Louis'den yaptığı Afrodit yani Zühre isimli çeviri Osmanlı Türkçesi'ne çevrilen ilk Venüs romanı olma özelliğini taşır. Yaklaşık iki yüz elli sayfalık bu roman daha önceden yayımlanmamış Venüs tasvirleri içerir. Bundan sonraki yıllarda, Nev-Yunanilik akımının da etkisiyle Antik Yunan mitolojisi Osmanlı yazınında yeniden canlanır.

\section{SONUÇ}

Mehmed Celâl'in Venüs romanından yola çıkılarak hazırlanmış bu çalışma, son dönem Osmanlı edebiyatının kendi içerisindeki çeşitliliğini ve Greko-Romen mitolojileriyle ilişkileniş biçimlerini görmeyi amaçlamaktadır. Bunu yaparken içerik ve biçimsel açıdan iki meseleyi odağına almaktadır: deniz hamamlarının alternatif bir kamusal alan olarak varlığı ve mitolojik unsurların klasik Osmanlı şiirindeki işleniş biçimleri. Kırk beş sayfalık bir metinden ibaret olan Venüs, mitolojik unsurları Osmanlı bağlamında yeniden oluşturduğu için oldukça ilginç

2 Venüs ve Aurora aslında Roma mitolojisinin tanrıçalardır. Ancak Mehmed Celâl her iki metninde de Antik Yunan mitolojisinden faydalandığını dile getirir.

3 “Orora, melek gibi bir kızdır. Orora Venüs'ten dünyaya gelmiş sanılacak derecede güzeldir. Ressamların levha üzerinde gösterebilecekleri derecede cazibeli, münevver bir çehreye mâliktir” (Mehmed Celâl, 1888, s. 5).

4 Bkz. EK. 
bir metindir. Hüseyin Cahit' in eleştirisinden de anlaşılacağı üzere, Mehmed Celâl'in kullandiğ 1 tasvirler ve ele aldığı konular dönemin kabul görmeye başlayan yeni edebiyat yazınıyla uyuşmaz. Edebi zevkteki bu kırılmalar, Mehmed Celâl'in ve metinlerinin unutulmasına ve edebiyat kanonu içerisine dahil edilmemesine yol açar. Ancak, romanları mevcut kriterler açısından zayıf olarak kabul edilse bile barındırdıkları melezlik hem Osmanlı romanını anlamada hem de onun diğer edebiyatlarla ilişkilerini görmede önemli ipuçları barındırır. Özellikle hikâyenin deniz hamamlarında geçen sahneler, Osmanlı kamusal alanını yeniden düşünmemiz için önemli ipuçları verir. Venüs'ün içerik ve biçim açısından barındırdığ 1 çoğulluğu anlamaya çalışmak, farklı edebiyatların bir araya gelirken ne gibi dönüşümlere uğrayıp birbirleri içerisinde nasıl eridiğini görebilmek arada kalmış nesillere yeni bakış açılarıyla bakabilmek adına değerlidir.

Hakem Değerlendirmesi: Dış bağımsız.

Çıkar Çatışması: Yazar çıkar çatışması bildirmemiştir.

Finansal Destek: Yazar bu çalışma için finansal destek almadığını beyan etmiştir.

Peer-review: Externally peer-reviewed.

Conflict of Interest: The author has no conflict of interest to declare.

Grant Support: The author declared that this study has received no financial support.

\section{KAYNAKÇA/REFERENCES}

Alus, S. M. (1947, 11 Haziran). Bir Vakitki Hususi Deniz Hamamları. Akşam Gazetesi, s. 4.

Alus, S. M. (1950, 19 Nisan). Çiftehavuzlar. Akşam Gazetesi. s. 5.

Andı, M. F. (1995). Ara Nesil Şairi Mehmed Celâl Hayatı Görüşleri Şiirleri. İstanbul: Alfa.

Andrews, W. G. (2012). Şiirin Sesi, Topumun Şarkısı: Osmanlı Gazelinde Anlam ve Gelenek. (T. Güney, Çev.). İstanbul: İletişim.

Beyoğlu, S. (2004). Osmanlı Deniz Hamamları. Yakın Dönem Türkiye Araştırmaları. 0, 5.

https://dergipark.org.tr/tr/pub/iuydta/issue/951/10717

Celal İsmail Paşa. (1900). Deniz Havası ve Hamamları. İstanbul: Hattat Serviçen Matbaası.

Gibb, E. J. W. (1999). Yeni Dönemin Doğuşu. Osmanlı Şiiri Tarihi III-IV-V. Ankara: Akçağ.

Gökçek, F. (2014). Bir Tartışmanin Hikâyesi Dekadanlar. İstanbul: Dergâh.

Hüseyin Hulki. (1893). Deniz Hamamlarl ve Kimler Girmelidir? İstanbul: Mahmud Bey Matbaası.

İbrahim Cemal. (1890). Deniz Hamamı Risalesi. İstanbul: Kasbar Matbaası.

Koçu, R. E. (1966). Deniz Hamamları. İstanbul Ansiklopedisi: Cilt. 8 içinde (s. 4438-4441). İstanbul: Koçu. Louis, P. (1913). Afrodit Yani Zühre. (Süleyman Tevfik, Çev.). İstanbul: Muvaffakiyet Kütüphanesi.

Mehmed Celâl. (1886). Venüs. İstanbul: Dikran Karabetyan Matbaası.

Mehmed Celâl. (1888). Orora. İstanbul: Kasbar Matbaası.

Mehmed Celâl. (1894). Büyük Hikâyeler ve Aksâmı. Osmanlı Edebiyatı Numûneleri içinde (s. 168-172). İstanbul: Matbaa-i Safâ ve Enver. 
Mehmed Celâl. (2014). Leman. Mehmed Celâl'in Hikâye ve Romanları (N. Şen, Haz.). Ankara: Kurgan Edebiyat.

Mehmed Tevfik. (1913). Esâtir-i Yunaniyan. İstanbul: Mekteb-i Harbiye Matbaası.

Strauss, J. (2014). Osmanlı İmparatorluğu'nda Kimler, Neleri Okurdu? (G. Ayaydın Cebe, Çev.) Uslu, M.

F. \& Altuğ, F. (Ed.). Tanzimat ve Edebiyat: Osmanlı İstanbulu'nda Modern Edebi Kültür içinde (s. 1-65). İstanbul: Türkiye İş Bankası.

Tevfik Fikret. (2017). Promete. Haluk'un Defteri. İstanbul: Karbon Kitaplar.

Toprak, Z. (2018). Deniz Hamamından Plaja Bir Nostaljinin Öyküsü. İstanbul'da Deniz Sefası içinde (s. 8-85). İstanbul: Pera Müzesi Yayını.

Tökel, D. A. (2000). Divan Şiirinde Mitolojik Unsurlar. Ankara: Akçağ.

Yüksel, S. (2010). Türk Edebiyatında Yunan Antikitesi (1860-1908). Sivas: Asitan. 


\section{EK: Mehmed Celâl'in 1899'da Mâlûmât Mecmuasında Yayımlanan Şiiri:}

\section{Venüs Denizden Çıkıyor}

Sisler iniyordu kûhsâre,

Olmuştu sehâib-i mülevven

Dâmân-1 ufukda pâre pâre,

Her pâresi başka türlü rûşen.

Kızmıştı perî-i nevbahâre

Uçmuştu şafak perîsi erken

Çeşmi seherin olunca giryân

Bir kız gibi doğdu mihr-i tâbân

Sâkindi deniz, sabâ-yı hoş-bû

Yapraklar içinde âh ederdi.

Bülbül denilen garîb-i hoş-gû

Bir pembe güle nigâh ederdi.

Sath-1 çemeni penâh ederdi.

Yaprakda olurdu jâle mühtez,

Bir gözyaşıdır düşer tükenmez.

Birden bire cûşa geldi deryâ,

Sâhilleri öptüler köpükler.

Emvâcın içinde oldu peydâ

Bir zemzeme kim sürûda benzer.

Bir kız oluyordu âşikârâ

Mahmûr nigâhı rûh-perver.

Gîsûsu omuzlarında lerzân,

Gönlüm gibi dâimâperîşân.

Ârâm-güzîn-i sâhil oldu

Tâbende köpüklerin içinde.

Mahûr idi, hâba mâil oldu

Bir sırmalı bisterin içinde.

Vaktâ ki humârı zâil oldu

Bir hiss-i mükedderin içinde

Gördü beni baş ucunda muğber,

Bir damla da yaş gözümde titrer.

Etti beni cezbesiyle teshîr

Bu vech ile başladım hitâba:

"Ey neyyir-i âlem-i esâtîr!

Bak bendeki müzmin 1ztırâba,

Birgün beni öldürürse takdîr,

Gel kabrime, böyle yaz kitâbe:

Âyinesidir bu taş melâlin

Fersûde mezârıdır Celâl'in

(And1, 1995, s. 228-229) 